\title{
Residential self-selection in the relationships between the built environment and travel behavior: Introduction to the special issue
}

\author{
Xinyu (Jason) Cao \\ Humphrey School of Public Affairs, University of Minnesota
}

A large number of studies have explored the relationships between the built environment and travel behavior since the 1990s. In most developed countries and fast-growing developing countries, suburban sprawl has been widely criticized for its contribution to auto dependence and associated consequences. Policymakers have implemented various strategies (such as smart growth, transit-oriented development, and eco-towns) to mitigate the impacts of sprawl development. Previous empirical studies seem to support the advocacy of land use and transportation policies to reduce auto dependence and increase the use of alternative means of transport (Ewing and Cervero 2010). However, they have yet to establish the predominant causal link: do people living in "walkable" neighborhoods walk more because the built environment itself "invites" them to do so, or because people who like to walk tend to choose residential neighborhoods conducive to exercising that preference? In this field, the latter phenomenon is called residential self-selection: people choose where to live based on their travel needs and preferences (Mokhtarian and Cao 2008).

Residential self-selection confounds the relationships between the built environment and travel behavior and thus carries important implications about the efficacy of land use and transportation policies for changing travel behavior. Therefore, it has become a critical issue in the debate over the relationships (TRB and IOM 2005). During the past decade, many studies have been conducted to implicitly and explicitly address the causal connections between the built environment and travel behavior. There is also a growing interest in the literature on environmental correlates of physical activity and obesity (McCormack and Shiell 2011). As the number of studies grows, it is time to evaluate research progress made, consider improvements needed, and stimulate innovative work. Further, different voices on the implications of the self-selection research to policy and planning practice have gradually emerged (Levine 2006; Næss 2009; Bhat and Eluru 2009; Boarnet and Crane 2001). This special issue offers a snapshot of different viewpoints and original research on the self-selection issue.

North American studies dominate the self-selection literature, although European scholars contribute (Van Dyck et al. 2011; Aditjandra, Cao, and Mulley 2012; De Vos et al. 2012; Van Acker, Mokhtarian, and Witlox 2011; Vance and Hedel 2007). The research on the built environment and travel behavior in general and residential self-selection in particular is still in its infancy in most developing countries, where urbanization is burgeoning and land use and transportation interventions can be critically effective in managing auto use. Wang and Lin pioneer their discussion on the self-selection issue in the context of China. The Chinese housing market is unique due to the coexistence of three major housing sources: housing allocated by working units (Danwei), commercial housing, and public housing. The Danwei housing and mobility instrument availability constrain individuals' residential choice. They further argue that location and travel choices are expected to be affected by Chinese-specific attitudes: preferences for short commuting, access to transit, proximity to daily shopping/service, and status-seeking. These discussions point to the importance of considering context-specific attributes

${ }^{\mathrm{a}}$ cao@umn.edu

Copyright 2014 Xinyu (Jason) Cao

Licensed under the Creative Commons Attribution - NonCommercial License 3.0. 
when exploring the connections between the built environment and travel behavior in developing countries.

Scheiner aims to orient the self-selection research in the context of mobility biography, which studies stability and changes in travel behavior induced by key events over an individual's life course. He discusses various issues related to residential choice, preferences, and implications for spatial and transport planning, and then calls for the biographical approach. He argues that travel behavior should be investigated in concert with other domains of an individual's life course, family biography, employment biography, and residential biography. He proposes a framework as a starting point to study mutual dependences among relocation, mobility, and preferences at various time points over a long period.

Similar to Scheiner, Zhang calls for a trans-disciplinary life-oriented approach to re-examine the self-selection issue. He contends that residential self-selection is not just attributable to demographic characteristics and travel/residential attitudes, but affected by individuals' life choice of different domains such as health and education. The empirical evidence from a life history survey (i.e., mobility biography) and a life choice survey conducted in Japan supports his statements. He concludes that effective land use and transportation policies should be designed with policies which affect individual life choices in other domains.

Chatman identifies the misunderstanding in previous studies on self-selection from three perspectives. First, individuals with different attitudes tend to respond to the changes in the built environment differently and hence an average treatment effect of the built environment on travel does not exist. Second, it depends on the specific research question of a study to determine whether the impacts of attitudes on travel behavior should be accounted for. Third, few studies have put the self-selection research in the context of housing supply and demand. He also questions the common practice of controlling for demographics in previous studies.

Although many scholars hold that ignoring self-selection in empirical studies carries important implications on land use and transportation policies, Næss argues that previous studies exaggerate its confounding effect. He characterizes the concern as a "tempest in a teapot" because travel-attitude-related self-selection is not a substantial threat to both the causal mechanism between the built environment and travel behavior and their empirical relationships in terms of parameter estimates. He conceptually justifies it from seven perspectives and offers empirical evidence. This paper is very notable because it questions the foundation of future self-selection research. Per my request, van Wee and Boarnet summarize the significant contribution of previous research and react to Næss's opinions. Næss responds to the commentary. This collection of debates represents a provocative and thorough discussion regarding the implications of the self-selection issue to planning research and practice.

It is evident that land use and transportation infrastructure helps improve quality of life (Cao 2013; Parra et al. 2010; Friedman et al. 2012). However, scholars speculate that the observed association between the built environment and quality of life results from residential self-selection. Cao and Ettema bring the self-selection research into the well-being literature. Using data collected for the Hiawatha (Blue Line) light rail transit (LRT) in the Twin Cities, they examine the influences of the built environment and residential self-selection on travel satisfaction. They find that attitudes play a significant role in explaining travel satisfaction, but that built environment characteristics also have an independent effect after controlling for demographics and attitudes. Their findings suggest that policies to build high quality transit have a positive effect on travel satisfaction in general, and for those with a transit preference in particular.

Overall, this issue collects the thoughts of some of the most prominent scholars in the area of residential self-selection. The viewpoints will guide the development of the self-selection research for years to come and be further tested by future studies. 


\section{References}

Aditjandra, Paulus Teguh, Xinyu Cao, and Corinne Mulley. 2012. Understanding neighbourhood design impact on travel behaviour: An application of structural equations model to a British metropolitan data. Transportation Research Part A: Policy and Practice 46 (1):22-32. http://dx.doi.org/10.1016/j. tra.2011.09.001.

Bhat, Chandra R., and Naveen Eluru. 2009. A copula-based approach to accommodate residential self-selection effects in travel behavior modeling. Transportation Research Part B: Methodological 43 (7):749-765. http://dx.doi.org/10.1016/j.trb.2009.02.001.

Boarnet, Marlon, and Randall Crane. 2001. Travel by design: the influence of urban form on travel, Spatial information systems. New York: Oxford University Press.

Cao, J. 2013. The association between light rail transit and satisfactions with travel and life: Evidence from Twin Cities. Transportation 40 (5):921-933. http://dx.doi.org/10.1007/s11116-013-9455-8.

De Vos, Jonas, Ben Derudder, Veronique Van Acker, and Frank Witlox. 2012. Reducing car use: changing attitudes or relocating? The influence of residential dissonance on travel behavior. Journal of Transport Geography 22 (0):1-9. http://dx.doi.org/10.1016/j.jtrangeo.2011.11.005.

Ewing, Reid, and Robert Cervero. 2010. Travel and the Built Environment -- A Meta-Analysis. Journal of the American PlanningAssociation 76(3):265-294.http://dx.doi.org/10.1080/01944361003766766.

Friedman, Dana, Nina Parikh, Nancy Giunta, Marianne Fahs, and William Gallo. 2012. The influence of neighborhood factors on the quality of life of older adults attending New York City senior centers: results from the Health Indicators Project. Quality of Life Research 21 (1):123-131. http://dx.doi. org/10.1007/s11524-011-9633-y.

Levine, Jonathan. 2006. Zoned Out: Regulation, Markets, and Choices in Transportation and Metropolitan Land-Use. Washington, DC: Resources for the Future.

McCormack, Gavin, and Alan Shiell. 2011. In search of causality: a systematic review of the relationship between the built environment and physical activity among adults. International Journal of Behavioral Nutrition and Physical Activity 8 (1):125. http://dx.doi.org/10.1186/1479-5868-8-125.

Mokhtarian, Patricia L., and Xinyu Cao. 2008. Examining the impacts of residential self-selection on travel behavior: A focus on methodologies. Transportation Research Part B: Methodological 42 (3):204-228. http://dx.doi.org/10.1016/j.trb.2007.07.006.

Næss, Petter. 2009. Residential Self-Selection and Appropriate Control Variables in Land Use: Travel Studies. Transport Reviews 29 (3):293-324. http://dx.doi.org/10.1080/01441640802710812.

Parra, Diana C., Luis F. Gomez, Olga L. Sarmiento, David Buchner, Ross Brownson, Thomas Schimd, Viviola Gomez, and Felipe Lobelo. 2010. Perceived and objective neighborhood environment attributes and health related quality of life among the elderly in Bogota, Colombia. Social Science \& Medicine 70 (7):1070-1076. http://dx.doi.org/10.1016/j.socscimed.2009.12.024.

TRB and IOM. 2005. Does the built environment influence physical activity? Examining the evidence Special report 282. Washington, DC: Transportation Research Board and Institute of Medicine.

Van Acker, Veronique, Patricia Mokhtarian, and Frank Witlox. 2011. Going soft: on how subjective variables explain modal choices for leisure travel. European Journal of Transport and Infrastructure Research 11 (2):115-146.

Van Dyck, Delfien, Greet Cardon, Benedicte Deforche, Neville Owen, and Ilse De Bourdeaudhuij. 2011. Relationships between neighborhood walkability and adults' physical activity: How important is residential self-selection? Health \& Place 17 (4):1011-1014.

Vance, Colin, and Ralf Hedel. 2007. The impact of urban form on automobile travel: disentangling causation from correlation. Transportation 34 (5):575-588. http://dx.doi.org/10.1007/s11116-0079128-6. 